\title{
New Agent in the Treatment of Cystinuria: $N$-acetyl-D-penicillamine
}

\author{
G. S. STOKES,* M.D., B.S. ; J. T. POTTS, jun.,† M.D. ; M. LOTZ, $\ddagger$ M.D. ; F. C. BARTTER,§ M.D.
}

Brit. med. F., 1968, 1, 284-288

Treatment of cystinuria with D-penicillamine, introduced by Crawhall, Scowen, and Watts (1963), has dramatically reduced morbidity due to cystine urolithiasis in selected patients, both by preventing new stone formation (Crawhall, Scowen, and Watts, 1964 ; Bartter, Lotz, Thier, Rosenberg, and Potts, 1965 ; MacDonald and Fellers, 1966) and by dissolving stones lodged in the renal pelvis (Lotz and Bartter, 1965; McDonald and Henneman, 1965). These effects were apparently based on formation of the more soluble mixed disulphide, penicillaminecysteine, in place of cystine. However, the administration of D-penicillamine involves a definite risk of complications, such as reactions resembling serum sickness, skin rash, nephrotic syndrome, agranulocytosis, impairment of taste sensation, and iron depletion. In addition, D-penicillamine inactivates pyridoxal-5-phosphate and gives rise to biochemical changes typical of pyridoxine deficiency in experimental animals (Asatoor, 1964) and in man (Jaffe, Altman, and Merryman, 1964). It also affects collagen metabolism, producing inhibition of wound-healing in normal rats (Nimni and Bavetta, 1965) and in patients after long-term treatment for Wilson's disease or cystinuria (Scheinberg, 1964 ; Harris and Sjoerdsma, 1966).

All three of the reactive sites of the $D$-penicillamine molecule -the $\alpha$-amino group, the sulphydryl group, and the terminal carboxyl group-are required for maximal metal-chelating activity (Aposhian, 1961) ; interference with pyridoxal phosphate involves at least two, the $\alpha$-amino and the sulphydryl (du Vigneaud, Kuchinskas, and Horvath, 1957). It is likely that the other undesirable side-effects are related to molecular configuration involving the participation of two or more of the reactive groups. The known actions of D-penicillamine in decreasing free urinary cystine in cystinuria involve only the sulphydryl group necessary to form a mixed disulphide with cysteine (Eldjarn and Hambraeus, 1964 ; Bartter et al., 1965). Thus it was of interest to study in cystinuric patients the effects of $N$-acetyl-D-penicillamine, a thiol structurally similar to D-penicillamine but lacking a free $\alpha$-amino group.

It was shown that $N$-acetyl-D-penicillamine is an effective therapeutic agent in cystinuria, causing a decrease in urinary free cystine by the same mechanisms as D-penicillamine, but lacking some toxic effects of the parent compound. Further, it was shown that restriction of dietary methionine, a precursor of cystine, can potentiate the effectiveness of $N$-acetyl-Dpenicillamine in cystinuria, and that alkalinization of the urine is also effective as adjunctive treatment.

\section{Materials and Methods}

Ten patients with homozygous cystinuria were studied, seven of whom had been previously treated for 3 to 36 months with

- Overseas Research Fellow of the National Heart Foundation of Australia, Clinical Endocrinology Branch, National Heart Institute, National Institutes of Health, Bethesda, Maryland, U.S.A. Present address: Medical Research Department, K
tute, Sydney Hospital, Sydney, Australia.

+ Chief, Section on Polypeptides, Laboratory of Metabolism, National Heart Institute, National Institutes of Health, Bethesda, Maryland, U.S.A.

₹ Clinical Endocrinology Branch, National Heart Institute, National Insttutes of Health, Bethesda, Maryland, U.S.A. Present address: tures of Feaith, Bethedicine, Georgetown Medical School, Washington, D.C., U.S.A.

5 Chief, Clinical Endocrinology Branch, National Heart Institure, National Institutes of Health, Bethesda, Maryland, U.S.A.
D-penicillamine 2 g./day. During a drug-free control period of 6 to 12 days routine haematological, renal, and hepatic function tests were carried out, two or more 24-hour urine collections were analysed for cystine, and serum copper and ceruloplasmin were determined; in one patient urinary iron and copper excretion were estimated by the methods of Gubler, Lahey, Ashenbrucker, Cartwright, and Wintrobe (1952) and Henry, Sobel, and Chiamori (1958), respectively. In six patients urinary excretion of kynurenine during 24 hours after a 2-g. oral load of L-tryptophan was determined by the method of Tompsett (1959). $N$-acetyl-penicillamine, 2 to $4 \mathrm{~g}$./day by mouth in equally divided six-hourly doses, was administered for a period of five days to five weeks. Haematological, liverfunction, and tryptophan-loading tests were repeated at weekly intervals ; serum copper, ceruloplasmin, and inulin and P.A.H. clearances were determined on one or more occasions; and the 24-hour urinary output of free cystine, $N$-acetylpenicillamine-cysteine mixed disulphide and cysteine-homocysteine mixed disulphide was measured daily or at intervals. Similar studies were also carried out in eight patients during a course of D-penicillamine 2 to $4 \mathrm{~g}$./day.

The procedures for collecting 24-hour urine specimens, for determining renal clearances, and for measuring cystine and mixed disulphides in urine and plasma were as described elsewhere (Stokes, Potts, Lotz, and Bartter, 1966a, 1968), except for a modification of the automatic amino-acid analyser system necessary for the determination of homocysteine-cysteine ; elution at $55^{\circ} \mathrm{C}$. with $0.2 \mathrm{M}$ sodium citrate $\mathrm{pH} 3.5$ buffer (68 $\mathrm{ml}$./hour) was followed after 30 minutes by $0.2 \mathrm{M}$ citrate $\mathrm{pH}$ 4.1 buffer containing $2.3 \%$ benzyl alcohol and $5 \%$ propanol.

\section{Results}

\section{Characteristics of $N$-acetyl-D-penicillamine and} N-acetyl-D-penicillamine-cysteine

$N$-acetyl-D-penicillamine (Fig. 1 ) is a white crystalline com pound (M.W.191.25) sparingly soluble in water and ninhydrinnegative owing to the lack of a reactive $\alpha$-amino group. The blocking of the $\alpha$-amino group was shown also to prevent inactivation of pyridoxal. Pyridoxal-5-phosphate in $0.1 \mathrm{M}$ phosphate $\mathrm{pH} 7.4$ buffer $(0.21 \mu \mathrm{mole} / \mathrm{ml}$.) has a pale green colour which fades rapidly on addition of D-penicillamine, 0.63

$$
\text { (1) Cystine: } \begin{aligned}
& \mathrm{NH}_{2} \\
& \mathrm{HOOC}-\mathrm{CH}_{\mathrm{H}}-\mathrm{CH}_{2}-\mathrm{S} \\
& \mathrm{HOOC}-\mathrm{C}_{\mathrm{N}}^{\mathrm{H}}-\mathrm{CH}_{2}-\mathrm{S} \\
& \mathrm{NH}_{2}
\end{aligned}
$$

(2) N-Acetyl-D-Penicillomine<smiles>CC(=O)NC(C(=O)O)C(C)(C)S</smiles>

(3) N-Acetyl-D-Penicillomine-Cysteine

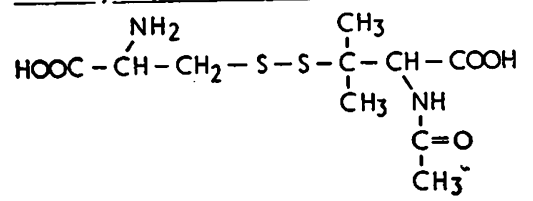

FiG. 1.-Structural formulae of cystine, of $\mathbf{N}$-acetyl-D-penicillamine, and of the mixed disulphide formed by their interaction. 
$\mu \mathrm{mole} / \mathrm{ml}$., as a new compound is formed, apparently a thiazolidine involving the sulphydryl and $\alpha$-amino groups of D-penicillamine (du Vigneaud et al., 1957). The absorption spectrum of this new compound is in the ultraviolet range. In contrast, the addition of an equimolar amount of $N$-acetyl-penicillamine to the pyridoxal-5-phosphate solution caused no loss of colour or shift in absorption spectrum.

$N$-acetyl-D-penicillamine-cysteine formed by disulphide interchange between $N$-acetyl-D-penicillamine and cystine in vitro and in vivo is ninhydrin-positive by virtue of the $\alpha$ amino group of cysteine. Like cysteine and cystine, it reacts with ninhydrin to produce a colour with lower absorbance at $570 \mathrm{~m} \mu$ than most other amino-acids and relatively high absorbance at $440 \mathrm{~m} \mu$. Its solubility in water is about 500 times that of cystine and 10 times that of D-penicillaminecysteine. $N$-acetyl-penicillamine, like $\mathrm{D}$-penicillamine, gives a positive reaction with the standard nitroprusside cyanide test (Lewis, 1932), while $N$-acetyl-penicillamine disulphide and $N$ acetyl-penicillamine-cysteine both give negative results. This observation suggested that the nitroprusside cyanide test could be used to assess decreases in urinary free cystine during treatment with $N$-acetyl-penicillamine, as has been reported in the case of D-penicillamine therapy (Lotz, Potts, and Bartter, 1965b). In two patients with similar daily cystine outputs cystine in urine samples collected before and during treatment with $N$-acetyl-penicillamine was estimated both by Spinco analysis and by a quantitative cyanide-nitroprusside test (Coxon and Kolb, 1954). The results are shown in Table I. They indicate that $N$-acetyl-D-penicillamine is effective in reducing urinary cystine and that the nitroprusside cyanide test provides a rough measure of the therapeutic effectiveness of $N$ acetyl-penicillamine, though it tends to overestimate cystine concentration.

TABl.E I.-Compartson of Spinco Analyser Method and Quantitative (yanide-nitroprusside Test in Determination of Urinary Free Cystine (mg./day)

\begin{tabular}{|c|c|c|c|c|c|}
\hline & Analyser & $\begin{array}{c}\text { Cyanide- } \\
\text { Nitroprusside }\end{array}$ & $\begin{array}{c}\text { Mean } \\
\text { Differences }\end{array}$ & S.E. & $\mathbf{P}$ \\
\hline $\begin{array}{l}\text { Before treatment }\left(\mathrm{n}^{*}\right. \\
=12) \\
\text { After } N \text {-acetyl-D-peni- } \\
\text { cillamine } 2-4 \mathrm{~g} \text {./day }\end{array}$ & 593 & 657 & +64 & \pm 37 & 0.2 \\
\hline$\left(n^{*}=15\right) \quad \ldots \quad$ & 137 & 165 & +28 & \pm 17 & 0.2 \\
\hline
\end{tabular}

$* n=$ Number of urine specimens.

\section{Effects of $\boldsymbol{N}$-acetyl-penicillamine on Urinary Excretion of Cystine in Cystinuria}

Typical results of treatment with $N$-acetyl-D-penicillamine, 2 to 4 g./day, in three cystinuric subjects are shown in Figs. 2,3 , and 4 .

Case 7 (Fig. 2).-A 38-year-old truck driver complained of intermittent passage of urinary gravel, which had been frequent and incapacitating for several months. After equilibration on a constant diet containing $70 \mathrm{~g}$. of protein per day and of normal methionine content, his urinary cystine averaged $911 \mathrm{mg}$./day in solution. In addition, 5 to $10 \mathrm{mg}$. appeared as small calculi in the urinary sediment each day. Cystine excretion fell to $520 \mathrm{mg}$. in the first 24 hours of treatment with $N$-acetyl-penicillamine $2 \mathrm{~g} . /$ day. It decreased progressively, and reached $370 \mathrm{mg}$./day a week later. At this time gravel was no longer found in the urinary sediment. When treatment with $N$-acetyl-penicillamine was increased to $4 \mathrm{~g}$./day there was a further small reduction in urinary cystine. Decrease in free cystine was associated with the appearance of the mixed disulphide, $\mathrm{N}$-acetyl-penicillamine-cysteine. On the third day after the drug was stopped the mixed disulphide was not detectable in urine, and free cystine excretion had increased nearly to the control level.

Case 1 (Fig. 3).-A 22-year-old housewife had undergone five nephrolithotomies between the ages of 14 and 19 . For the past three years she had been successfully maintained on D-penicillamine 2 g./day and a diet relatively low in methionine. With a constant 30-g. protein, low methionine diet, and no other treatment her urinary cystine excretion averaged $488 \mathrm{mg}$./day (Fig. 3). After treatment with $\mathrm{N}$-acetyl-penicillamine $2 \mathrm{~g}$ /day for four days and 4 g./day for three days her urinary free cystine had decreased to less than $100 \mathrm{mg} . /$ day.

$N$-acetyl-penicillamine thus reduced urinary cystine to lower values in Case 1 than in Case 7. The possibility that this difference could derive from the adjunctive effect of the lowmethionine intake in Case 1 was investigated in Case 3.

Case 3.-This patient was a 47-year-old businessman (Fig. 4). After equilibration on a diet containing $70 \mathrm{~g}$. of protein and $1.9 \mathrm{~g}$ of methionine per day his urinary cystine averaged $695 \mathrm{mg} . / \mathrm{day}$.

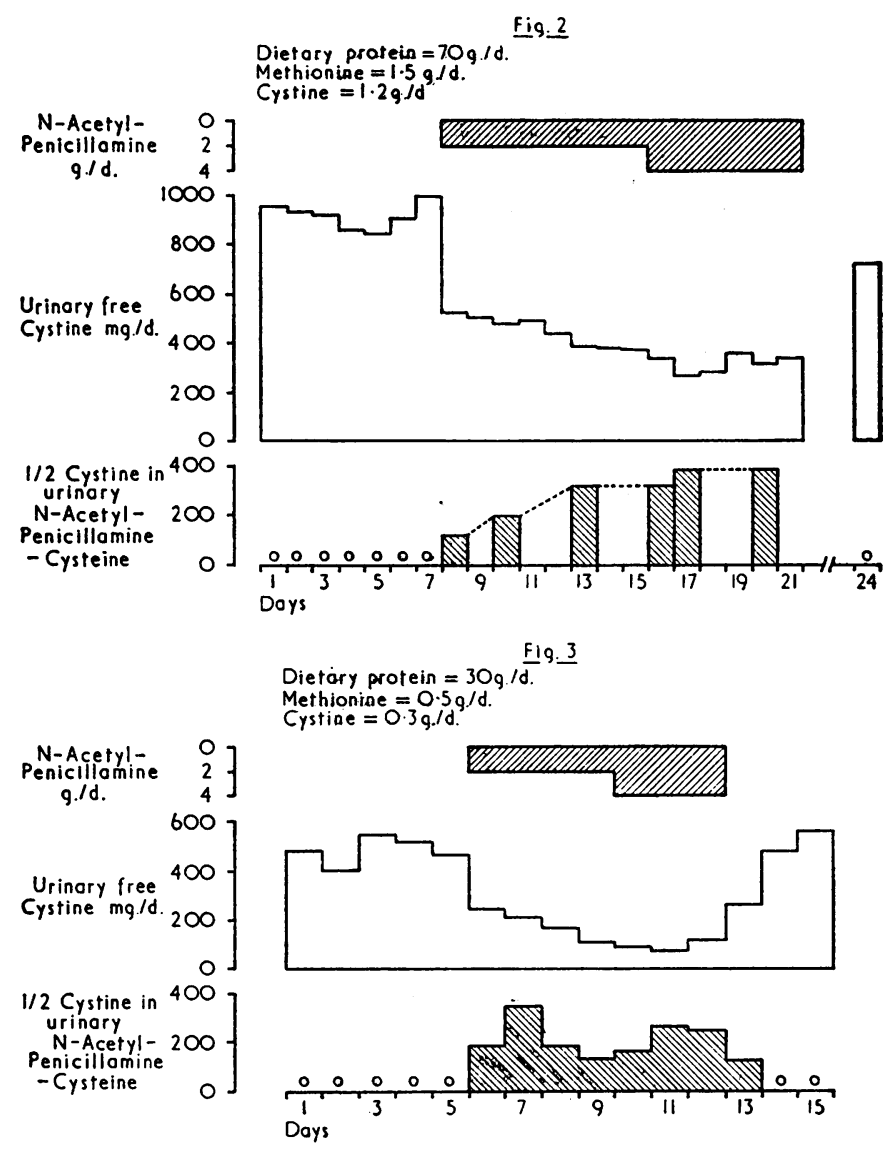

Fig. 4 .

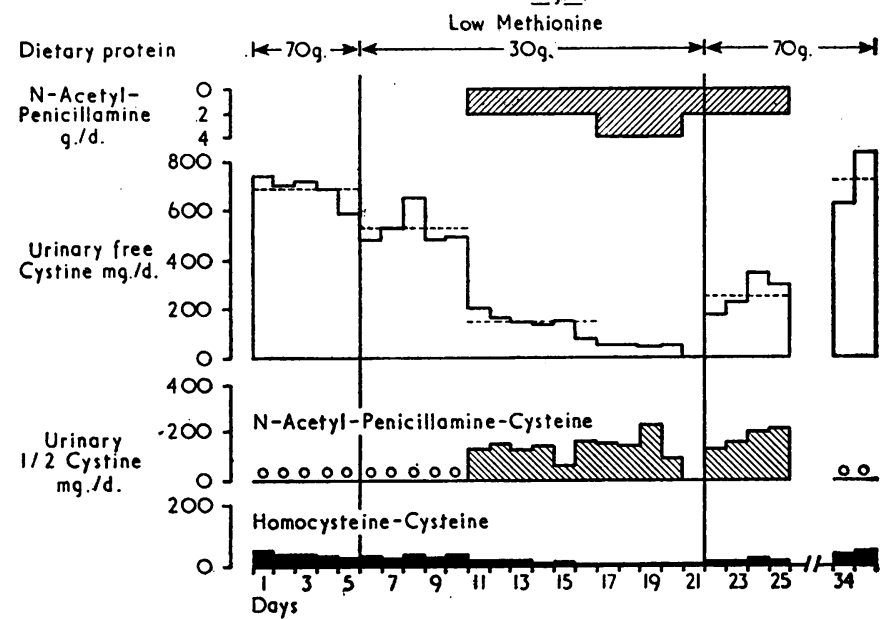

FIG. 2.-Case 7. Effect of $\mathbf{N}$-acetyl-penicillamine on urinary free cystine and on urinary $N$-acetyl-penicillamine-cysteine in a 38-year-old man with cystinuria. FIG. 3. - Case 1. Effect of N-acetyl-penicillamine on urinary free cystine and on urinary $N$-acetyl-penicillamine-cysteine in a 22-yearold woman with cystinuria. Fig 4.-Case 3. Effect of dietary methio nine and of $N$-acetyl-penicillamine on urinary cystine, $N$-acetylpenicillamine-cysteine, and homocysteine-cysteine in a 47-year-old man with cystinuria. 
TABle II.-Average Urinary Free Cystine (mg./day) Before and After Treatment with Penicillamines. (Standard Errors are Shown in Parentheses; Where no Standard Error is Given, the Value is Based on One Observation Only)

\begin{tabular}{|c|c|c|c|c|c|c|c|c|c|c|c|}
\hline & \multicolumn{6}{|c|}{ Patients on $30 \mathrm{~g}$. Protein, Low Methionine Diet } & \multicolumn{5}{|c|}{ Patients on $70-$ g. Protein Diet } \\
\hline & Case 1 & Case 2 & Case 3 & Case 4 & Case 5 & Case 6 & Case 7 & Case 3 & Case 8 & Case 6 & Case 9 \\
\hline $\begin{array}{l}\text { Before treatment } \\
N \text {-Acetyl-D- } \\
\text { penicillamine } \\
2 \text { g./day } \\
\begin{array}{l}2.56 \mathrm{~g} . / \text { day } \\
4 \mathrm{~g} . / \text { day }\end{array}\end{array}$ & $\begin{array}{l}488( \pm 22) \\
126( \pm 36) \\
78( \pm 13)\end{array}$ & $\begin{array}{l}679( \pm 42) \\
258( \pm 54) \\
78\end{array}$ & $\begin{array}{l}520( \pm 34) \\
133( \pm 16) \\
44( \pm 1)\end{array}$ & $\begin{array}{l}532( \pm 103) \\
219( \pm 19) \dagger\end{array}$ & $\begin{array}{c}1270( \pm 142) \\
403( \pm 33)\end{array}$ & $199 \overline{( \pm 14) t}$ & $\begin{array}{l}911( \pm 21) \\
418( \pm 20) \\
308( \pm 17)\end{array}$ & $\begin{array}{c}695( \pm 31) \\
258( \pm 36) \\
=\end{array}$ & $\begin{array}{l}587( \pm 16) \\
307 \overline{( \pm 21)}\end{array}$ & $258(\underline{ \pm} 16) t$ & $401 \overline{( \pm 17)^{+}}$ \\
\hline $\begin{array}{l}\text { D-Penicillamine } \\
\begin{array}{c}2 \text { g./day } \\
4 \text { g./day }\end{array}\end{array}$ & $60( \pm 13)$ & ${ }^{132}-$ & $\overline{-}$ & $258( \pm 87) t$ & $\overline{-}$ & $154( \pm 0) t$ & $\begin{array}{r}293 \\
82\end{array}$ & $173( \pm 22)$ & - & $149( \pm 1) t$ & $214( \pm 5) t$ \\
\hline
\end{tabular}

* Equimolar with 2 g. D-penicillamine. t Restults paired for comparison of equimolar drug dosages.

Reduction of protein and methionine intake to $30 \mathrm{~g} . /$ day and 470 mg./day, respectively, resulted in a slight decrease in urinary cystine to $520 \mathrm{mg}$./day $(\mathrm{P}<0.01)$. While this diet was continued, treatment with $\mathrm{N}$-acetyl-penicillamine was started. With a dosage of 2 g./day urinary cystine decreased to values less than $150 \mathrm{mg}$./day; with a dosage of $4 \mathrm{~g} . /$ day it decreased to less than $50 \mathrm{mg}$./day. The dietary intake of methionine was then restored to the initial amount of $1.9 \mathrm{~g}$./day while $N$-acetyl-penicillamine was continued at a dosage of 2 g./day (Fig. 4, days 22-25). Urinary free cystine increased to values significantly greater $(P<0.05)$ than those found at this dosage of $N$-acetyl-penicillamine with the low-methionine intake (days 11-25). Values of urinary homocysteine-cysteine are also shown in Fig. 4. It is of theoretical interest that excretion of this mixed disulphide showed changes qualitatively similar to those observed in urinary free cystine during the study.

Table II gives averaged results for urinary free cystine in nine patients treated with $\mathrm{N}$-acetyl-penicillamine. Cystine excretion was decreased 45 to $75 \%$ on a dosage of 2 to $2.56 \mathrm{~g}$./ day and 65 to $90 \%$ on a dosage of $4 \mathrm{~g}$./day. Results obtained with $\mathrm{D}$-penicillamine are shown for comparison. In four studies the effectiveness of equimolar amounts of the two drugs in reducing urinary cystine was compared in the same patients. In two of these studies, during which dietary methionine was in the normal range (Table II), D-penicillamine $2 \mathrm{~g}$./day was significantly more effective than $\mathrm{N}$-acetyl-penicillamine $2.56 \mathrm{~g}$./ day. In the other two studies, during which dietary methionine was restricted, no significant difference was observed between the effectiveness of the two drugs.

In view of the known influence of $\mathrm{pH}$ on disulphide interchange in vitro (Eldjarn and Hambraeus, 1964) the importance of urinary $\mathrm{pH}$ in the reaction between $\mathrm{N}$-acetyl-penicillamine and cystine in the urinary tract was assessed by comparing the pattern of urinary disulphide excretion during mild metabolic acidosis with that during mild metabolic alkalosis. The results in one patient (Case 8) are shown in Table III. N-acetyl-D-

TABLE III.-Results in Case 8

\begin{tabular}{|c|c|c|c|c|c|}
\hline Day & $\begin{array}{c}\text { Average } \\
\text { Urinary } \\
p \mathbf{H}\end{array}$ & $\begin{array}{c}\text { Free } \\
\text { Cystine } \\
\text { (mg./day) }\end{array}$ & $\begin{array}{c}\text { Cystine in } \\
N \text {-Acetyl- } \\
\text { Pen.-1/2 Cys. } \\
\text { (mg./day) }\end{array}$ & $\begin{array}{c}\text { Total } \\
\text { Cystine } \\
\text { (mg./day) }\end{array}$ & $\begin{array}{c}\text { N-Ac.-Pen.- } \\
\text { 1/2 Cys. } \\
\text { Total } \\
\text { Cys. }\end{array}$ \\
\hline $\begin{array}{l}1 \\
2 \\
3 \\
4\end{array}$ & $\begin{array}{l}-7.5 \\
7.5 \\
7.5\end{array}$ & $\begin{array}{l}2 \overline{297} \\
304 \\
206\end{array}$ & $\begin{array}{l}2 \overline{236} \\
155 \\
246\end{array}$ & $\begin{array}{l}5 \overline{33} \\
459 \\
452\end{array}$ & $\begin{array}{l}0 . \overline{4} \\
0.44 \\
0.54\end{array}$ \\
\hline $\begin{array}{c}5-7 \\
8 \\
9 \\
10\end{array}$ & $\begin{array}{l}\overline{5.0} \\
5.0 \\
5.0\end{array}$ & $\begin{array}{l}392 \\
307 \\
340\end{array}$ & $\begin{array}{l}\overline{59} \\
73 \\
72\end{array}$ & $\begin{array}{l}451 \\
380 \\
412\end{array}$ & $\begin{array}{l}0 \cdot 13 \\
0 \cdot 19 \\
0 \cdot 17\end{array}$ \\
\hline $\begin{array}{c}11-13 \\
14\end{array}$ & $\overline{7.5}$ & $3 \overline{302}$ & 125 & 427 & 0.29 \\
\hline
\end{tabular}

Oral medication: $N$-acetyl-D-penicillamine $2.56 \mathrm{~g}$./day for days $1-14$; alkalinizing Oral medication: $\mathrm{N}$-acetyl-D-penicillamine $2 \cdot 56 \mathrm{~g}$./day for days $1-14$; alkalinizing
ggent $\left(\mathrm{NaHCO}_{3}, 12 \mathrm{~g} / \mathrm{d}\right.$.) for days $1-4,11-14 ;$ acidifying agent $\left(\mathrm{NH}_{4} \mathrm{Cl}, 6 \mathrm{~g} / \mathrm{d}\right.$.) for days 5-10.

penicillamine $2.56 \mathrm{~g}$./day was given throughout the study. The urine was made alkaline by administration of sodium bicarbonate, $12 \mathrm{~g}$./day, or acid by administration of ammonium chloride, 6 g./day. When the urinary $\mathrm{pH}$ averaged 7.5 the mean ratio of $\mathrm{N}$-acetyl-penicillamine-cysteine to total cystine was 0.40 ; when the urinary $\mathrm{pH}$ averaged 5.0 , the ratio was 0.16. Thus there was less formation of the mixed disulphide from free cystine in acid urine.

\section{Effects of $\mathbf{N}$-acetyl-D-penicillamine on Plasma Cystine}

Plasma cystine values before and after four days of treatment with $N$-acetyl-penicillamine 2 or $2.56 \mathrm{~g}$./day are shown in Fig. 5. In each of four patients there was an appreciable reduction in free cystine in plasma $(P<0.06)$, though the effect was not as great $(P<0.1)$ as observed with $\mathrm{D}$-penicillamine $2 \mathrm{~g}$./day $(P<0.005)$. Four to five days after treatment with either drug was stopped, the plasma cystine concentration had returned to control values.

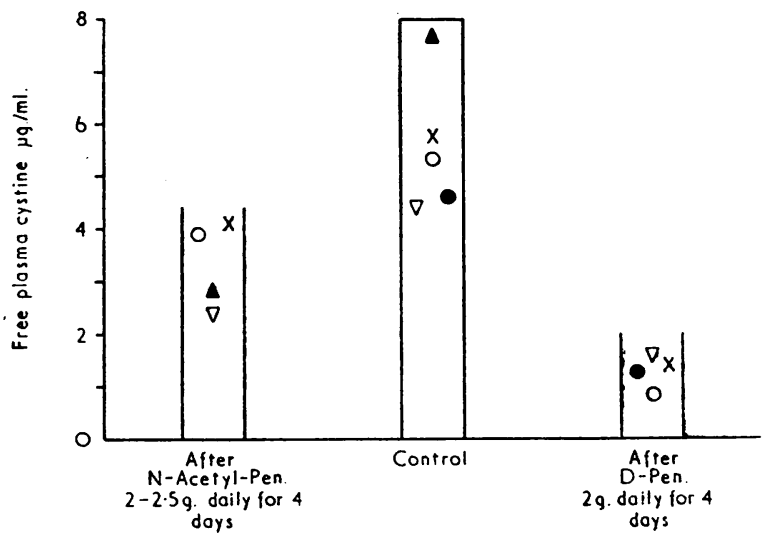

FIg. 5.-Free plasma cystine $(\mu \mathrm{g} . / \mathrm{ml}$ ) in five patients with cystinuria before treatment (central column), after treatment with $N$-acetyl-penicillamine, 2 to $2.5 \mathrm{~g}$./ day (left column), and/or after treatment with D-penicillamine $2 \mathrm{~g}$./day (right column). Each patient is denoted by a different symbol. Values shown have been corrected for recovery ( $86 \pm 5$ (S.E.)\%).

\section{Evaluation of $\mathbf{N}$-acetyl-penicillamine for Possible Side-effects}

No untoward effect attributable to $N$-acetyl-penicillamine was observed during a total of 155 treatment days, except for a transient episode of facial swelling and pruritus, possibly attributable to a hypersensitivity reaction, in one patient during the fourth week of treatment. No change in routine blood, renal, or liver-function tests was observed in any of the patients.

After a standard (2 g.) tryptophan load, 24-hour kynurenine excretion in five patients with cystinuria and five normal volunteers averaged $9 \mathrm{mg} . / 24$ hours (range 4-27). To test for the possibility that $N$-acetyl-penicillamine acts as a pyridoxine antagonist the tryptophan-loading test was repeated at weekly intervals during treatment with $N$-acetyl-penicillamine $2-4$ g./ day for two weeks in five patients, and for four weeks in two further patients. Kynurenine excretion remained within the range of control values. At the conclusion of each study pyridoxine hydrochloride, $100 \mathrm{mg}$. intramuscularly twice a day, was administered for two days, and the tryptophan-loading test was repeated. No significant decrease in kynurenine excretion was observed as a result of pyridoxine treatment; this suggests that $N$-acetyl-penicillamine had not caused even a minor degree of pyridoxine deficiency during the period of treatment. 
In five patients there was no significant change in the renal clearance of inulin or P.A.H. as a result of treatment with $N$ acetyl-penicillamine 2 to $4 \mathrm{~g}$./day; thus the drug does not interfere with renal haemodynamics or with the renal transport mechanism for P.A.H. The urinary excretion of iron and copper was measured every second day in one patient during the first two weeks of therapy. No change was apparent in the urinary excretion of copper. Control values for urinary iron excretion were 0.43 and $0.57 \mathrm{mg}$./day. On the first day of $\mathrm{N}$-acetyl-penicillamine $2.56 \mathrm{~g}$./day the value obtained was 0.04 $\mathrm{mg}$./day ; subsequent second daily results were $0.07,0.54,0.11$, $0.43,0.21$, and $0.54 \mathrm{mg}$./day. No significant depression of serum iron, serum copper, or ceruloplasmin was observed.

\section{Discussion}

The use of D-penicillamine in the therapy of cystinuria has been opposed on the grounds of its toxicity (Dent, Friedman, Green, and Watson, 1965). It is of considerable interest that $N$-acetyl-D-penicillamine, which provides an effective alternative to D-penicillamine in the specific therapy of cystinuria, is potentially less toxic in several respects.

Firstly, the blocking of the $\alpha$-amino group appears to prevent thiazolidine formation with pyridoxal-5-phosphate, the likely basis for the known propensity of $\mathrm{D}$-penicillamine to produce pyridoxine deficiency. Also, repeated tryptophan-loading tests in patients treated with $N$-acetyl-D-penicillamine produced no evidence of pyridoxine antagonism by this drug within the first four weeks of its administration. These findings are in contrast to those reported for D-penicillamine by Jaffe et al. (1964), who consistently observed raised kynurenine excretion in response to the standard tryptophan-loading test within the first one to two weeks of therapy.

Secondly, the elimination of one of the ionic groups important in chelate formation should decrease any side-effects resulting from depletion of trace metals. The potent cupriuretic effect of $\mathrm{D}$-penicillamine in patients with Wilson's disease is well documented (Walshe and Clarke, 1965). D-Penicillamine has also been shown to increase the urinary excretion of lead, iron, mercury, and zinc (Goldberg, Smith, and Lochhead, 1963 ; Boulding and Baker, 1957 ; Scheinberg, 1964 ; Aposhian, 1961). $N$-acetyl-penicillamine has been reported to have no cupriuretic effect in Wilson's disease (Scheinberg, 1964 ; it caused no appreciable change in copper excretion in one patient in the present study. While it is at least as potent as D-penicillamine in protecting against the lethal effects of mercuric chloride (Aposhian and Aposhian, 1959), this action probably depends on the simple combination of the sulphydryl group with mercury by a double bond rather than on true chelation (Williams, 1961). No significant decrease in serum iron or change in total iron-binding capacity was observed in this investigation, and urinary excretion of iron showed only a transient diminution in one patient studied. Increase in urinary iron excretion with $\mathrm{D}$-penicillamine has been reported in one patient with haemosiderosis (Boulding and Baker, 1957), and iron deficiency has been observed in long-term studies (Scheinberg, 1964, Lotz, Potts, Holland, Kiser, and Bartter, 1966). However, the ability of D-penicillamine to deplete essential body stores of iron has been questioned (Walshe and Clarke, 1965). Certainly, any such action must be slight and gradual, and long-term comparative study of both drugs would be necessary to establish any advantage for $N$-acetyl-penicillamine therapy in this respect.

Another potential advantage of $N$-acetyl-penicillamine relates to the incidence of hypersensitivity reactions during the early stages of therapy. Only one patient (out of the series of 10) developed symptoms suggesting a hypersensitivity response in the present study. This patient had previously exhibited a severe but transient allergic reaction during the first four days of her treatment with D-penicillamine (Lotz et al., 1966), but had since been uneventfully treated with $D$-penicillamine for a year. The recurrence of hypersensitivity during treatment with $N$-acetyl-penicillamine in her case suggests a lack of allergic cross-reactivity between the two drugs. The absence of any sign of allergic reaction in the other nine patients treated with $\mathrm{N}$-acetyl-penicillamine is of interest in view of the incidence of hypersensitivity in cystinuric patients treated with D-penicillamine. Out of a total of 32 patients in four reported series, $13(41 \%)$ developed morbilliform rashes, fever, upper respiratory tract symptoms, or other clear evidence of an allergic reaction (Crawhall et al., 1964; Lotz, Potts, and Bartter, 1965a ; MaDonald and Henneman, 1965 ; MacDonald and Fellers, 1966).

D-Penicillamine therapy has been associated with impairment of renal function (Goldberg et al., 1963) and with the onset of the nephrotic syndrome (Fellers and Shahidi, 1959 ; Sternlieb and Scheinberg, 1964). No change in urinary sediment, serum creatinine, blood urea nitrogen, or P.A.H. and inulin clearances was seen in the present studies. Long-term investigation will be needed to show whether $N$-acetyl-penicillamine can produce such side-effects-reported in D-penicillamine therapy -as agranulocytosis, loss of taste sensation, or degeneration of collagenous tissues.

The roles of dietary methionine restriction and of alkali therapy in the treatment of cystinuria have been long disputed (Patch, 1934 ; Smith, Kolb, and Harper, 1959 ; Dent et al., 1965 ; MacDonald and Fellers, 1966 ; Zinneman and Jones, 1966). Generally it appears that either of these measures alone, or even a combination of both, is ineffective in preventing recurrence of cystine calculi in some patients. However, it has been shown in the present investigation that each can act as an important adjunct to $N$-acetyl-penicillamine in the treatment of cystinuria. While it is not recommended that the patient be persuaded to adhere strictly to a $30-\mathrm{g}$. protein diet, lesser degrees of methionine restriction can be achieved with a generally acceptable level of protein intake (Smith et al., 1959). Such restriction, together with $N$-acetyl-penicillamine, may help reduce urinary cystine to the range (200 to $300 \mathrm{mg}$./day) at which stone formation is unlikely to occur. Similarly, alkalinization of the urine not only increases the solubility of urinary free cystine, but also favours the formation of the soluble mixed disulphide, $N$-acetyl-penicillamine-cysteine (Table III).

The actions of penicillamines are not attributable to mixed disulphide formation alone but may result in part from an effect on the transport of cystine or cystine-precursor in extrarenal tissues (Stokes, Potts, Lotz, and Bartter, 1966b, 1968). In the present study D-penicillamine appeared to be more effective than $N$-acetyl-penicillamine in reducing urinary cystine excretion when dietary methionine was unrestricted; also, it produced a greater depression of plasma cystine. These differences may derive from a more potent extrarenal action of $D$. penicillamine.

\section{Summary}

$N$-acetyl-D-penicillamine, 2 to $4 \mathrm{~g}$./day, produced significant reduction in free cystine in the urine and plasma of 10 patients with cystinuria.

The decrease in free cystine was associated with the appearance in the urine of a highly soluble mixed disulphide, $N$ acetyl-penicillamine-cysteine.

Restriction of dietary methionine and alkalinization of the urine were each shown to provide a useful adjunctive effect during treatment of cystinuria with $\mathrm{N}$-acetyl-penicillamine, as each resulted in a further decrement in urinary cystine.

$N$-acetyl-penicillamine, with the reactive $\alpha$-amino group blocked, is potentially less toxic than D-penicillamine. It has less anti-pyridoxal effect both in vitro and in vivo; it probably has a lower affinity for trace metals. 
One mild hypersensitivity reaction was observed in this series of 10 patients, in contrast to a $41 \%$ incidence of reactions in cystinurics treated with D-penicillamine in four other reported series. None of the other side-effects reported elsewhere for D-penicillamine was observed in this study.

Thanks are due to Dr. E. Alpert, Merck Sharp \& Dohme, West Point, Pa., U.S.A., for generous supplies of D-penicillamine and $N$-acetyl-D-penicillamine used in these studies.

\section{REFERENCES}

Aposhian, H. V. (1961). Fed. Proc., 20, Suppl. No. 10, p. 185

and Aposhian, M. M. (1959). F. Pharmacol. exp. Ther., 126, 131. Asatoor, A. M. (1964). Nature (Lond.), 203, 1382.

Barter, F. C., Lotz, M., Thier, S., Rosenberg, L. E., and Potts, J. T., jun. (1965). Ann. intern. Med., 62, 796.

Boulding, J. E., and Baker, R. A. (1957). Lancet, 2, 985.

Coxon, V., and Kolb, F. O. (1954). Metabolism, 3, 255

Crawhall, J. C., Scowen, E. F., and Watts, R. W. E. (1963). Brit. med. †., 1,588 .

(i964). Ibid., 1, 1411.

Dent, C. E., Friedman, M., Green, H., and Watson, L. C. A. (1965). Ibid., 1, 403.

du Vigneaud, V., Kuchinskas, E. J., and Horvath, A. (1957). Arch. Biochem., 69, 130. Eldjarn, L., and Hambraeus, L. (1964). Scand. F. clin. Lab. Invest., 16,

Fellers, F. X., and Shahidi, N. T. (1959). Amer. F. Dis. Child., 98, 669.
Goldberg, A., Smith, J. A., and Lochhead, A. C. (1963). Brit. med. J., 1, 1270.

Gubler, C. J., Lahey, M. E., Ashenbrucker, H., Cartwright, G. E., and Wimtrobe, M. M. (1952). F. biol. Chem., 196, 209.

Harris, E. D. jun and Sjoerdsma, A (1966). Lancet, 2, 996.

Henry, R. J., Sobel, Ch., and Chiamori, N. (1958). Clin. chim. Acta, 3, S23.

Jaffe, I. A., Altman, K., and Merryman, P. (1964). \}. clin. Invest., 43, 1869.

Lewis, H. B. (1932). Ann. intern. Med., 6, 183.

Lotz, M., and Bartter, F. C. (1965). Brit. med. ๆ., 2, 1408.

- Potts, J. T., jun., and Bartter, F. C. (1965a). Milit. Med., 130, 768.

(1965b). Brit. med. 7., 2, 521

Holland. J. M., Kiser, W. S., and Bartter, F. C. (1966). 3. Urol., 95, 257.

McDonald, J. E., and Henneman, P. H. (1965). New Engl. Ұ. Med., 273, 578 .

MacDonald, W. B., and Fellers, F. X. (1966). F. Amer. med. Ass., 197. 396.

Nimni, M. E., and Bavetta, L. A. (1965). Science, 150, 905.

Patch, F. S. (1934). Canad. med. Ass. F., 31, 250.

Scheinberg, I. H. (1964). 7. chron. Dis., 17, 293.

Smith, D. R., Kolb, F. O., and Harper, H. A. (1959). F. Urol., 81, 61.

Sternlieb, I., and Scheinberg, I. H. (1964). F. Amer. med. Ass., 189, 748.

Stokes, G. S., Potts, J. T., jun., Lotz, M., and Bartter, F. C. (1966a). Clin. Res., 14, 390. (1966b). Abstracts of 3rd International Congress on Nephrology, p. 280.

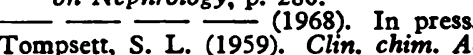

Tompsett, S. L. (1959). Clin. chim. Acta, 4, 411.

Walshe, J. M., and Clarke, V. (1965). Arch. Dis. Childh., 40, 651

Williams, R. J. P. (1961). Fed. Proc., 20, Suppl. No. 10, p. 190.

Zinneman, H. H., and Jones. J. E. (1966). Metabolism, 15, 915.

\title{
Comparison of Symptoms after Vagotomy with Gastrojejunostomy and Partial Gastrectomy
}

\author{
ALAN G. COX, * M.D., F.R.C.S.ED.
}

Brit. med. F., i $968,1,288-290$

The choice of operation for chronic duodenal ulcer has been debated vigorously but opinion remains divided. Properly controlled prospective clinical trials are needed to provide a true comparison between the effects of different operations. Such a trial to evaluate the results of the Polya partial gastrectomy with vagotomy and gastrojejunostomy has been conducted at the Western Infirmary, Glasgow, since 1954. This paper reports a comparison of symptoms in patients who were treated at least eight years ago.

\section{Method of Study}

Male patients coming to elective surgery for chronic duodenal ulcer were treated either by total vagotomy with gastrojejunostomy or by the Polya partial gastrectomy. The choice of operation was determined by random selection after exploration of the abdomen had confirmed the diagnosis and shown that either operation could be performed with safety.

All patients operated on at least eight years previously were included. Of 106 patients available for study 55 had had a partial gastrectomy and 51 vagotomy with gastrojejunostomy (Table I). The two groups of patients showed striking similarities when age, height, weight, and time since operation were compared (Table II).

Each patient underwent an interview which lasted 30 to 40 minutes. In order to ensure standard conditions each interview comprised a series of identical questions asked in the same order and with a minimum of prompting and discussion. Most

- Department of Surgery, Western Infirmary, Glasgow. Present address : Department of Surgery, Royal Postgraduate Medical School, Ducane Road, London W.12. questions related to alimentary symptoms, and, if present, their severity was noted as mild, moderate, or severe. The patients were then asked to give their own opinion of the symptomatic outcome of the operation by choosing one of four descriptions : no alimentary symptoms, mild symptoms, moderate symptoms, severe symptoms. Finally, they were placed in one of the following clinical grades: grade 1, no alimentary symptoms; grade 2, mild, easily controlled symptoms; grade 3 , poorly controlled symptoms which did not interfere significantly with enjoyment of life or capacity for work; grade 4, symptoms which did interfere with enjoyment of life or capacity for work ; or grade 5 , recurrent ulcer or severe symptoms.

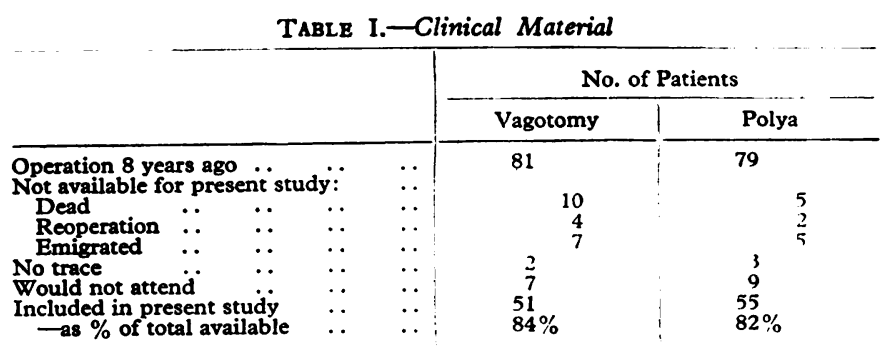

TABLB II.-Similarity of Patients After the Two Different Operations

\begin{tabular}{|c|c|c|c|c|}
\hline & & & \multicolumn{2}{|c|}{ Mean \pm S.D. } \\
\hline & & & Vagotomy & Polya \\
\hline $\begin{array}{l}\text { Age in years } \\
\text { Height in cm. } \\
\text { Weight in kg. } \\
\text { Months since operation }\end{array}$ & $\begin{array}{l}\because \\
\because \\
\cdots\end{array}$ & \begin{tabular}{l|}
$\because$. \\
$\therefore$
\end{tabular} & $\begin{array}{c}48 \cdot 3 \pm 8 \cdot 4 \\
170 \cdot 1 \pm 6 \cdot 9 \\
62 \cdot 9 \pm 7 \cdot 2 \\
102 \cdot 4 \pm 17 \cdot 1\end{array}$ & $\begin{array}{c}49 \cdot 8 \pm 8 \cdot 7 \\
169 \cdot 0 \pm 6 \cdot 5 \\
61 \cdot 1 \pm 7 \cdot 6 \\
104 \cdot 7 \pm 12 \cdot 3\end{array}$ \\
\hline
\end{tabular}

